\title{
Desenvolvimento socioeconômico brasileiro entre 1990 e 2012: considerações sobre a informalidade do trabalho à luz da teoria do duplo movimento de Polanyi*
}

\author{
Juliano Vargas ${ }^{* *}$
}

\begin{abstract}
Resumo
Esse estudo examina os nexos de convergência entre o desenvolvimento socioeconômico e a evolução da informalidade no mercado nacional de trabalho no interregno 1990-2012, à luz da teoria do duplo movimento de Polanyi. Duas fases são fundamentais para a discussão pretendida: a) fim do século XX, em que o Brasil passou por reformas que resultaram no aumento da informalidade no mercado de trabalho; b) início do século XXI, com renovada participação política do Estado e da sociedade civil, que gerou diminuição moderada do trabalho informal. A concepção polanyiana de duplo movimento mostra-se como instrumento útil para a compreensão primeiro da "grande transformação" e na sequência também para o entendimento do "contramovimento" (parcial), ambos verificados no país após 1990. Conclui-se que o caminho para mitigar a historicamente alta informalidade no Brasil transpassa pelo desincrustamento desse hábito enraizado da sociedade em geral.
\end{abstract}

Palavras-chave: Desenvolvimento Brasileiro. Informalidade do Trabalho. Polanyi.

JEL: J46, J82, N46.

\section{Introdução}

A pesquisa aborda o desenvolvimento socioeconômico brasileiro entre 1990 e 2012, com foco no exame do fenômeno da informalidade ${ }^{1}$ no mercado de trabalho. As questões

\footnotetext{
*Agradeço aos editores e aos dois pareceristas anônimos por suas sugestões construtivas. O autor é extremamente grato aos comentários de André Augusto Michelato Ghizelini, Ednilson Silva Felipe e de Silvia Leticia dos Santos. Obviamente, os equívocos e omissões remanescentes são de minha inteira responsabilidade.

***Doutorando em Economia pela Universidade de Brasília (UnB). E-mail: brazil.juliano@gmail.com

${ }^{1}$ São controversas as tentativas de definições estritas acerca da informalidade. Nesse artigo adotarse-á o arcabouço conceitual estabelecido pela Organização Internacional do Trabalho, observadas as leis trabalhistas prevalentes no Brasil e considerando-se a atual configuração do mundo do trabalho. Nesta perspectiva, se assume que uma coisa é a informalidade nas relações de trabalho - como, por exemplo, o emprego sem carteira de trabalho assinada - e outra são relações de produção informais, que podem ocorrer,
} 
básicas a serem discutidas são as seguintes: a) Quais foram os acontecimentos do fim do século XX que tiveram como efeito o aumento da informalidade no mercado nacional de trabalho? b) De forma análoga, que eventos e desdobramentos resultaram em diminuição moderada do trabalho informal no início do século XXI? c) Qual o caminho a ser trilhado para mitigar o problema da informalidade no país? É nesse sentido que se pretende aplicar a teoria do duplo movimento de Polanyi à análise da informalidade no Brasil.

Esse estudo é definido por um delineamento de caráter qualitativo, caracterizandose como um ensaio, tanto pelo método que utiliza quanto por seu estilo de escrita, que conta com a exposição dos fatos acompanhados das argumentações julgadas pertinentes. Quanto ao escopo teórico, a pesquisa baseou-se em fontes secundárias relativas à evolução socioeconômica contemporânea do Brasil, contrastadas com a concepção teórica de Polanyi. Isso possibilitou formar um marco teórico que favoreceu a investigação da informalidade do trabalho. A pesquisa se justifica uma vez que não há arranjo investigativo que estabeleça relações similares, não tendo sido encontrada pesquisa que propusesse análise semelhante e/ou conjunta do desenvolvimento socioeconômico e do mercado informal de trabalho no Brasil, a partir da obra de Polanyi, em qualquer que fosse o período de interesse.

Dentre os escritos desse autor, especialmente a obra chamada "A grande transformação" (2012a) será empregada na abordagem da informalidade. Calcado em questionamentos quanto ao funcionamento do sistema de livre mercado e aos seus efeitos deletérios para os indivíduos e para o desenvolvimento socioeconômico em geral, a pesquisa de Polanyi apresenta um enfoque sistêmico que abarca os campos de estudo das Ciências Sociais (Antropologia, Sociologia e Política), Economia, História, Direito e Filosofia. Entendese que esta é uma característica essencial constituinte também deste estudo.

Esse artigo é composto por três seções. Na primeira seção expõe-se a teoria do duplo movimento de Polanyi, estabelecendo relações dela com o mercado informal de trabalho brasileiro. Na segunda analisa-se como se engendrou o aprofundamento da desregulamentação do sistema econômico brasileiro no interregno 1990-1999, juntamente com seus efeitos e implicações no mundo do trabalho e na sociedade brasileira. Na terceira examina-se o processo de retomada econômica e de inserção internacional do Brasil no início do século XXI, mediante condução mais ativa do Estado inclusive em termos de políticas sociais, o que favoreceu a diminuição moderada da informalidade.

por exemplo, com a existência de trabalhos por conta própria, ocupações sem registro ou em empresas informais; a última é a perspectiva empregada neste estudo. Para fins didáticos, mais a frente no texto será utilizada pontualmente (nos gráficos 1 e 2) uma das três definições estatísticas formuladas pelo IBGE/PNAD a título de mostrar as tendências do grau da informalidade (GI) entre 1990 e 2012, sem comprometimento da análise teórica a ser empreendida. Ver Vargas (2016).

Econômica-Niterói, v. 19, n. 2, p. 155-180. dezembro, 2017 


\section{Polanyi e a teoria do duplo movimento: relações com o Brasil infor- mal}

A teoria do duplo movimento é um conceito central da obra "A Grande Transformação" (POLANYI, 2012a). Originalmente ela foi endereçada à criação, na Inglaterra novecentista, do sistema de mercado autorregulável - imposição de mercados livres e flexíveis, isto é, a "grande transformação" - e de como sua instabilidade intrínseca acentuou, dentre outras coisas, a incerteza e a precariedade social e laboral. Segundo o autor, sua implantação deu-se sob a égide das denominadas "mercadorias fictícias": trabalho (seres humanos), terra (natureza) e dinheiro, que segundo ele possuem qualidades próprias que não podem ser expressas pela racionalidade do mercado.

De acordo com o argumento do autor, das mudanças sociais e institucionais resultantes do surgimento da economia de mercado e da estrutura capitalista provieram profundas alterações na organização produtiva, especialmente a do trabalho ${ }^{2}$, com que o livre funcionamento do mercado no capitalismo poderia levar a rupturas no tecido social. Polanyi afirmava que disso decorria, invariavelmente, um "contramovimento" como a busca de salvaguardas institucionais via pressões por proteção social, reagindo assim às perturbações coletivas que mercados autorregulados impunham à vida das pessoas.

$\mathrm{O}$ conflito em relação à segurança laboral funciona como um movimento pendular entre a flexibilidade dos mercados e a segurança da proteção social. As origens da "catástrofe [conflitos dos séculos XIX e XX] residiam no esforço utópico do liberalismo econômico para configurar um sistema de mercado autorregulado" (POLANYI, 2012a, p. 30). Isso porque sociedades de mercado não resultam de "instituições naturais, que surgiriam espontaneamente se apenas se deixassem os homens em paz" (POLANYI, 2012a, p. 290), mas da intervenção política sistemática. Note-se que o autor rejeita o que chamava de "falácia" do mercado autorregulável (POLANYI, 1957, 1977a, 2012b). Dois excertos ilustram seu argumento:

"(1) Os mercados de trabalho, terra e dinheiro são, sem dúvida, essenciais para uma economia de mercado. Entretanto, nenhuma sociedade suportaria os efeitos de um tal sistema de grosseiras ficções, mesmo por um período de tempo muito curto, a menos que a sua substância humana natural, assim como a sua organização de negócios, fosse protegida contra os assaltos desse moinho satânico (POLANYI, 2012a, p. 95).

(2) Enquanto, de um lado, os mercados se difundiam sobre toda a face do globo e a quantidade de bens envolvidos assumiu proporções inacreditáveis, de outro uma rede de medidas e políticas se integravam em poderosas instituições destinadas a cercear a ação do mercado relativa

\footnotetext{
${ }^{2}$ Para Polanyi (2012a, p. 192), "trabalho e terra nada mais são que os seres humanos nos quais consistem todas as sociedades e o ambiente natural no qual elas existem", e, ainda, o "trabalho é apenas outro nome para a atividade humana que acompanha a própria vida".
} 
158 Desenvolvimento socioeconômico brasileiro entre 1990 e 2012: considerações sobre a informalidade do trabalho à luz da teoria do duplo movimento de Polanyi

ao trabalho, a terra e ao dinheiro. Enquanto a organização dos mercados mundiais de mercadorias, dos mercados mundiais de capitais e dos mercados mundiais de moedas [...] deu um momentum sem paralelo ao mecanismo de mercados, surgiu um movimento bem estruturado para resistir aos efeitos perniciosos de uma economia controlada pelo mercado. A sociedade se protegeu contra os perigos inerentes a um sistema de mercado autorregulável (POLANYI, 2012a, p. 98)."

Polanyi considera os mercados instituições importantes, aceitando que as sociedades complexas não podem prescindir deles. Entretanto, o autor diferencia o sistema de mercado dos mercados. O ponto crítico era que o primeiro se sobrepunha à sociedade, alicerçado tão somente pela lei da oferta e da procura. Cabe salientar que ele era contrário à opinião de que apenas o Estado deveria ter a prerrogativa de regular a economia, pois para ele os problemas econômicos tinham raiz social e não política. Assim, deveriam ser resolvidos via transformação social e cultural. O poder estatal não era capaz de solucionálos (POLANYI, 1957, 1977a, 1977b, 2012b). Por isso, sustenta que a liberdade pessoal é fundamental e

"existirá na medida em que criarmos deliberadamente salvaguardas para a sua manutenção, e até para a sua ampliação. Numa sociedade estabelecida, o direito a não conformidade deve ser protegido institucionalmente. $\mathrm{O}$ indivíduo deve ser livre para seguir a sua consciência, sem recear os poderes incumbidos das tarefas administrativas em algumas áreas da vida social (POLANYI, 2012a, p. 296)."

Polanyi adverte que o comportamento humano não é exclusivamente guiado pela racionalidade econômica e que as instituições não se resumem àquelas unicamente derivadas do sistema de mercado. Para ele, as ações humanas são resultantes de comportamentos tanto individuais quanto sociais não maximizadores. Desaprova o utilitarismo ${ }^{3}$, portanto. Ele discorda dessa interpretação como sendo um axioma próprio da natureza humana, em que a sociedade, pautada por essa lógica, situa o sistema de mercado como "o objetivo de todo o progresso" (POLANYI, 2012a, p. 290). Para ele,

\begin{abstract}
"a verdadeira crítica à sociedade de mercado não é pelo fato de ela se basear na economia - num certo sentido, toda e qualquer sociedade tem que se basear nela - mas que a sua economia se baseava no autointeresse. Uma tal organização de vida econômica é inteiramente antinatural, no sentido estritamente empírico de excepcional (POLANYI, 2012a, p. 289)."
\end{abstract}

Polanyi defendia que o predomínio do mercado autorregulado afasta as pessoas do meio sociocultural que constitui a matriz da existência humana. Como alternativa, preconizava uma organização institucional que permitisse às pessoas viverem suas vidas através

\footnotetext{
${ }^{3} \mathrm{Na}$ Economia, o utilitarismo é entendido como um princípio segundo o qual: (a) os agentes maximizam funções de utilidade e/ou de lucro; (b) sua atuação corresponde a uma situação de maximização a partir do critério de otimalidade de Pareto, em que não é possível melhorar a situação de um agente sem piorar a de outro.
}

Econômica-Niterói, v. 19, n. 2, p. 155-180. dezembro, 2017 
do respeito mútuo e da cooperação. Por esse motivo, o autor sustentava que "em vez de existir uma economia incrustada (embedded) nas relações sociais, são as relações sociais que estão incrustadas no sistema econômico" (POLANYI, 2012a, p. 192). Ademais, partilhava da ideia de que as instituições e a cultura dominantes influenciavam na percepção que as pessoas tinham de si mesmas, mas não a ponto de serem completamente definidas pelo sistema ao qual faziam parte. Para ele, até na moderna sociedade capitalista as pessoas não são totalmente determinadas pelas suas motivações econômicas. Nas suas vidas cotidianas, elas também exercem a solidariedade, a amizade e o amor (POLANYI, 1957, 2012b).

Sua visão parte da assunção de que as instituições que organizam a provisão dos bens necessários à vida - a economia substantiva - são emanações humanas e têm forte influência dos hábitos e da cultura. Isso, por sua vez, interfere naquilo que os indivíduos vão poder ser e fazer (POLANYI, 2012a). Ademais, o valor econômico e o poder político são inevitáveis e entrelaçados em uma sociedade complexa. Logo, o desafio fundamental é o de saber qual o lugar e a configuração institucional das transações mercantis, da redistribuição e da reciprocidade, já que todas são imprescindíveis em uma sociedade funcional. Certamente não era o modelo de mercado autorregulável (POLANYI, 1957, 1977a, 1977b, 2012b). Assim, é possível estabelecer uma relação importante entre a tese de Polanyi e a informalidade do trabalho, ora seja, uma concepção de sociedade que pode ser modelada de modo que a economia funcione em conformidade com as leis socialmente construídas e estabelecidas, as quais não são imutáveis ao longo do tempo; daí a assertiva de Polanyi (2012a, p. 77) de que "uma economia de mercado só pode funcionar numa sociedade de mercado".

É nessa perspectiva que se defende a tese de que a alta informalidade historicamente verificada no Brasil tem origens que extrapolam a seara estritamente econômica. A cultura e os hábitos enraizados, como se pretende mostrar ao longo do texto, são componentes essenciais para o entendimento da não superação desse entrave ao desenvolvimento socioeconômico do país. Tal argumento corrobora a concepção - fulcral na teoria do duplo movimento - de que "a economia do homem, como regra, está submersa em suas relações sociais" (POLANYI , 2012a, p. 65). Ambas são reflexos da maior ou menor participação social ativa no que tange aos seus interesses coletivos. Considera-se que a sua efetivação - uma quebra de hábito enraizado no caso da sociedade brasileira, no sentido de não consentir com a alta informalidade do trabalho por encará-la como a concretização da precariedade da própria existência humana em todos os níveis - é que pode reduzi-la ${ }^{4}$ de modo consistente e sustentado no país.

Há correlação entre a abordagem teórica proposta por Polanyi e a visão de diversos autores e instituições que lidam diretamente com o tema do mercado de trabalho contem-

\footnotetext{
${ }^{4}$ É importante salientar que se emprega o termo redução e congêneres, ao invés de, por exemplo, eliminação, assumindo-se que devido às características e complexidades da informalidade no Brasil, não é razoável propor erradicá-la por completo. Aliás, tal fenômeno existe em todas as sociedades capitalistas.
} 
160 Desenvolvimento socioeconômico brasileiro entre 1990 e 2012: considerações sobre a informalidade do trabalho à luz da teoria do duplo movimento de Polanyi

poraneamente, como será visto mais adiante. Isso quanto às interpretações sobre o mundo do trabalho - especialmente o de natureza informal, a importância da sociedade e de suas instituições para o desenvolvimento socioeconômico, proteção do tecido social e garantia dos direitos individuais e coletivos do trabalho. O trabalho, além de assegurar a vida material, tem fundamental relevância para a autonomia dos indivíduos, a construção da identidade e o reconhecimento social. Há convergência, portanto, quanto à necessidade de que a sociedade e suas instituições sejam elementos ativos no processo de desenvolvimento das diferentes sociedades. Ao indivíduo deve-se oportunizar que desfrute de toda a liberdade possível, ora seja, a delimitada pelas relações sociais.

Nesse ínterim, cabe também destacar as afinidades existentes entre a abordagem desenvolvida por Polanyi e as conexões possíveis dessa com as leituras existentes acerca do mercado de trabalho brasileiro (no que se refere à multiplicidade de instituições envolvidas no processo, por exemplo), por ambas enfatizarem a primazia da construção e das especificidades históricas da sociedade em oposição aos ditames da economia puramente de mercado. Essa concepção a respeito do trabalho denota que o seu teor compõe um processo social mais amplo, de uma história que opõe os seres humanos e seus interesses e lhes condiciona o fazer de maneira assaz distinta da verificada pela economia estritamente concorrencial. Ao considerar o processo histórico e social, permite-se a inserção de novos elementos de análise. Nesse sentido, a maneira como os homens organizamse para produzir modifica-se de período para período e, tanto o modo geral como eles se articulam quanto os próprios conteúdos específicos dos diferentes trabalhos exercidos, mudam e assumem novas roupagens.

Dado o exposto, as seções seguintes têm a intenção de interpretar como se deu a "grande transformação" e seu "contramovimento" no Brasil entre o fim do século XX e início do século XXI, bem como aclarar a trajetória que o país percorreu no que se refere à informalidade do trabalho e ao desenvolvimento socioeconômico nesse período.

\section{Fim do século XX e reconfiguração do mundo do trabalho: a "grande transformação"}

\subsection{Antecedentes: breves considerações}

De 1930 a 1980, o Brasil foi marcado pela célere evolução socioeconômica e do mercado de trabalho, com transformações que favoreceram vínculos mais duradouros entre empregados e empregadores. Nesse período, o país deixou de ser uma sociedade agrárioexportadora para tornar-se (majoritariamente) urbano-industrial, sob a atuação fortemente indutora do Estado. Todavia, a crescente concentração urbana da população resultou no aumento da pobreza e de atividades atreladas à informalidade, alheias às garantias sociais de proteção aos cidadãos. Com efeito, houve descompasso entre um pujante crescimento econômico e um anêmico desenvolvimento social.

Econômica-Niterói, v. 19, n. 2, p. 155-180. dezembro, 2017 
Na década de 1980 o "modelo" de substituição de importações foi obstado devido à crescente vulnerabilidade externa do Brasil. A queda do dinamismo econômico converteuse em uma grave crise fiscal do Estado. Deste panorama irrompeu uma crise no Estado brasileiro, com que aumentaram as críticas ao seu papel e à legislação trabalhista. A Constituição da República Federativa do Brasil (BRASIL, 1988) (doravante CF/88) foi o marco das relações trabalhistas nessa década e a esperança da implantação de um Estado de bem-estar social ${ }^{5}$. Constitucionalizaram-se os direitos já garantidos pela legislação pré-existente e ampliaram-nos, formalizou-se o Sistema de Seguridade Social ${ }^{6}$ ao qual foi concedido o status de direitos e garantias fundamentais dos cidadãos, inalienáveis do trabalhador, independentemente da vontade do Estado ou do legislador ordinário. Todavia, a CF/88 contrastou com o cenário econômico existente, opondo-se ao projeto do Executivo, o que serviu como justificativa para emendas constitucionais precoces.

Essa conjuntura adversa degenerou em uma crise do mundo do trabalho e a reestruturação produtiva foi a opção escolhida para tentar retomar o crescimento. A pífia performance econômica precipitou a transição para a especialização flexível ${ }^{7}$, com aumento da insegurança laboral mesmo no final dos anos oitenta. O quadro institucional suscitou o aumento relativo da informalidade, desvelando as características assimétricas da evolução socioeconômica no Brasil. Entretanto, nesse período o núcleo duro das estruturas industriais e produtivas foi sustentado e o aumento do emprego no setor público também corroborou para minimizar os impactos dessas alterações.

Sumarizando, da débâcle da economia brasileira nos anos oitenta proveio uma crise do Estado, justificativa para o não compromisso formal por parte do governo com o pleno emprego, caracterizando uma contraposição aos princípios jurídicos vigentes. Na esteira destes acontecimentos iniciou-se a deterioração do mundo do trabalho, com aumento da insegurança laboral e, consequentemente, acréscimos na histórica exposição dos cidadãos a atividades precárias e informais. Seus desdobramentos fizeram-se sentir na década seguinte.

\footnotetext{
${ }^{5} \mathrm{O}$ Estado de bem-estar social é um tipo de organização política e econômica que coloca o Estado como agente da promoção (protetor e defensor) social e organizador da economia. Nessa orientação, o Estado é o agente mediador da vida social, política e econômica do país em parceria com sindicatos e empresas privadas, em níveis diferentes, de acordo com cada país. Cabe ao ele garantir serviços públicos e proteção à população. O "Estado de Bem-estar Social tem na sua origem três conceitos históricos distintos, que seriam o Estado-Providência francês, o Estado Social alemão e o Welfare State de origem anglo-saxã" (MAGNI e CALVETE, 2005, p.2).

${ }^{6} \mathrm{O}$ Sistema Seguridade Social, de modo geral, consiste em um conjunto de políticas sociais com a finalidade de amparar e assistir o cidadão e a sua família em situações como a velhice, a doença e o desemprego. No Brasil, a seguridade social é composta por três pilares: Previdência Social, Assistência Social e Saúde Pública, sendo as duas primeiras diretamente associadas ao trabalho. Ver a CF/88, Título VIII, Capítulo II.

${ }^{7}$ A especialização flexível caracteriza-se pela massificação das Tecnologias de Informação e Comunicação (TICs) na produção. As TICs - muitas delas poupadoras de mão de obra - correspondem a todas as tecnologias que interferem e mediam os processos informacionais e comunicativos interpessoais. Ver Lévy (1990).
} 
162 Desenvolvimento socioeconômico brasileiro entre 1990 e 2012: considerações sobre a informalidade do trabalho à luz da teoria do duplo movimento de Polanyi

\subsection{O desenvolvimento socioeconômico e a informalidade do trabalho entre 1990 e 2002}

Os anos noventa no Brasil foram marcados pelo aprofundamento da desregulamentação do sistema econômico, transferindo-se boa parte da coordenação da economia para as forças globais de mercado. Essa década se caracterizou por uma série de reformas voltadas, mormente, à estabilização interna e à maior inserção mundial.

Em 1994, o país instituiu o Real, considerado um dos mais bem sucedidos planos de estabilização monetária da economia brasileira. Seu sucesso permitiu a redução significativa dos níveis inflacionários. O câmbio sobrevalorizado e os juros altos, apesar de seus efeitos para o controle da inflação, restringiram o crescimento econômico e aumentaram a vulnerabilidade externa, além de prejudicarem as contas públicas.

Nesse ínterim, a discussão sobre a necessidade de abertura econômica floresceu ${ }^{8}$. Norteados para essa finalidade, quatro aspectos se sobressaíram na economia brasileira. Foram eles: i) abertura comercial, ii) nova política industrial, iii) programa de privatizações, iv) liberalização financeira com crescente vulnerabilidade externa. Esses aspectos tiveram conjuntamente impactos significativos na estrutura social, produtiva e no mercado de trabalho (YANO e MONTEIRO, 2006; LACERDA et al, 2010; GIAMBIAGI et al, 2011).

Justapõem-se a esses eventos econômicos dois fatores institucionais importantes que marcaram o cenário nacional nesse período: o aprofundamento de reformas que redundaram na redefinição do papel do Estado e uma miríade de alterações na legislação trabalhista. Portanto, a década de 1990 inaugurou um novo momento da história de sua administração pública. O discurso de modernização econômica do Estado foi gradativamente se consolidando na segunda metade dos anos oitenta e início dos anos noventa, embora circunscrito apenas a algumas áreas de sua estrutura. Todavia, de 1995 em diante uma reforma de Estado se efetivou institucionalmente, tornando-se um objetivo geral com um sentido amplo. Isto resultou na diminuição de seu aparato administrativo, ao contrário do que previa originalmente a CF/88. Nesse sentido, o Plano Diretor da Reforma do Aparelho de Estado (BRASIL, 1995) oficializou o discurso de "redefinição do papel do Estado", enfatizando as variáveis organizacional e gerencial.

Essencialmente, propôs-se passar de um "Estado-empresário e de bem-estar social" para o que seria um "Estado regulador e fiscal" das atividades econômicas. Em que pese a crise do Estado, a abordagem econômica stricto sensu omitiu as contradições resultantes da nova ordem econômica mundial ${ }^{9}$. Destarte, abordar o processo de redefinição do papel do Estado como derivação mecânica da lógica de incentivar a competição e a eficiência

\footnotetext{
${ }^{8}$ Para a discussão pormenorizada sobre a abertura econômica nos países emergentes, ver Rodrik (1997).

${ }^{9}$ A nova ordem econômica mundial surgiu do conjunto de propostas elaboradas e expressas pelas Nações Unidas, em 1974. Incorporou também o Consenso de Washington, resultante do encontro do Institute for International Economics nos Estados Unidos, em 1989. O objetivo alegado era diminuir a disparidade de poder nas relações econômicas entre países industrializados e emergentes. Ver Williamson (1989) e Rajagopal (2003).
}

Econômica-Niterói, v. 19, n. 2, p. 155-180. dezembro, 2017 
induz à supressão dos aspectos político-econômicos implícitos na concorrência imposta à fatia do "mercado" de serviços parcialmente geridos até então pelo Estado brasileiro.

Quanto às políticas econômicas adotadas pelo Governo Federal no período para levar a cabo tal desiderato, as ponderações de Polanyi são oportunas para avaliar seus desdobramentos. Para ele, os custos sociais do capitalismo desregulamentado são multifacetados e desconsiderados pelo mecanismo automático de preços, que não raramente geram danos à sociedade em geral, tais como: crises financeiras, perda da identidade cultural, insegurança laboral - como a precarização do trabalho e o alto grau de informalidade verificado no Brasil, por exemplo -, dentre outros (POLANYI, 1957, 2012a).

$\mathrm{Na}$ seara trabalhista, a regulamentação do mercado de trabalho foi flexibilizada. Esse processo evoluiu de forma descontínua, mas acumulou resultados consistentes com a proposta de flexibilização do mundo do trabalho. Excetuando-se as conquistas obtidas mediante acordos ou convenções coletivas, desde a $\mathrm{CF} / 88$ praticamente todas as alterações nos direitos trabalhistas promovidos no final do século $\mathrm{XX}$ foram no sentido de diminuí-los e/ou de intensificar o ritmo de trabalho.

Essas alterações "não vêm descoladas de um sentido mais amplo, qual seja, o da própria reforma do Estado", que, na área do trabalho, em sintonia com os preceitos da redefinição do papel do Estado no Brasil, visou "desregulamentar e flexibilizar as condições de uso, remuneração e proteção da força de trabalho" (CARDOSO JR. 2002, p. 921).

Quanto à reestruturação produtiva e a expansão da informalidade, pode-se afirmar que os anos 1990-2002 foram negativos no que se refere ao mundo de trabalho. Como visto, o desempenho titubeante da economia brasileira e as substanciais alterações institucionais nas relações trabalhistas colaboraram substancialmente no sentido de piorar a situação, o que contribuiu para a deterioração dos indicadores do mercado de trabalho, que degeneraram em alta expressiva do grau de informalidade.

Verificou-se uma tendência de aumento do GI até 1999, sendo que se manteve sempre em patamares bem superiores a 50\%. O pico da série foi registrado em $1999(59,6 \%)$, enquanto o vale foi registrado no ano de 1992 (56,4\%). Como o trabalho informal implica em negar uma série de direitos trabalhistas e sociais, a inexistência de tais proteções é entendida como um forte indicador de empregos de baixa qualidade. Houve, portanto, uma precarização do emprego no Brasil através da crescente informalização.

Destarte, pode-se asseverar que nesse intervalo de tempo o Brasil passou por uma reconfiguração do mundo do trabalho, em que os resultados para a dinâmica do mercado nacional de trabalho foram: i) redução de postos de trabalho amparados pelas instituições trabalhistas; ii) desemprego estrutural ${ }^{10}$, mormente derivado da desproporção qualitativa entre demanda e oferta de trabalho, devido, sobretudo, à inadequação do tipo de qualifi-

\footnotetext{
${ }^{10} \mathrm{~A}$ análise feita por Ramos (2002) reforça a visão de que o aumento da informalidade estaria mais associado a um componente estrutural do que cíclico. O autor chama a atenção para as significativas mudanças na composição setorial da ocupação ocorridas no mercado de trabalho urbano durante a década de 1990.
} 
164 Desenvolvimento socioeconômico brasileiro entre 1990 e 2012: considerações sobre a informalidade do trabalho à luz da teoria do duplo movimento de Polanyi

Gráfico 1 - Grau de informalidade (\%) - Brasil (1992-2002)

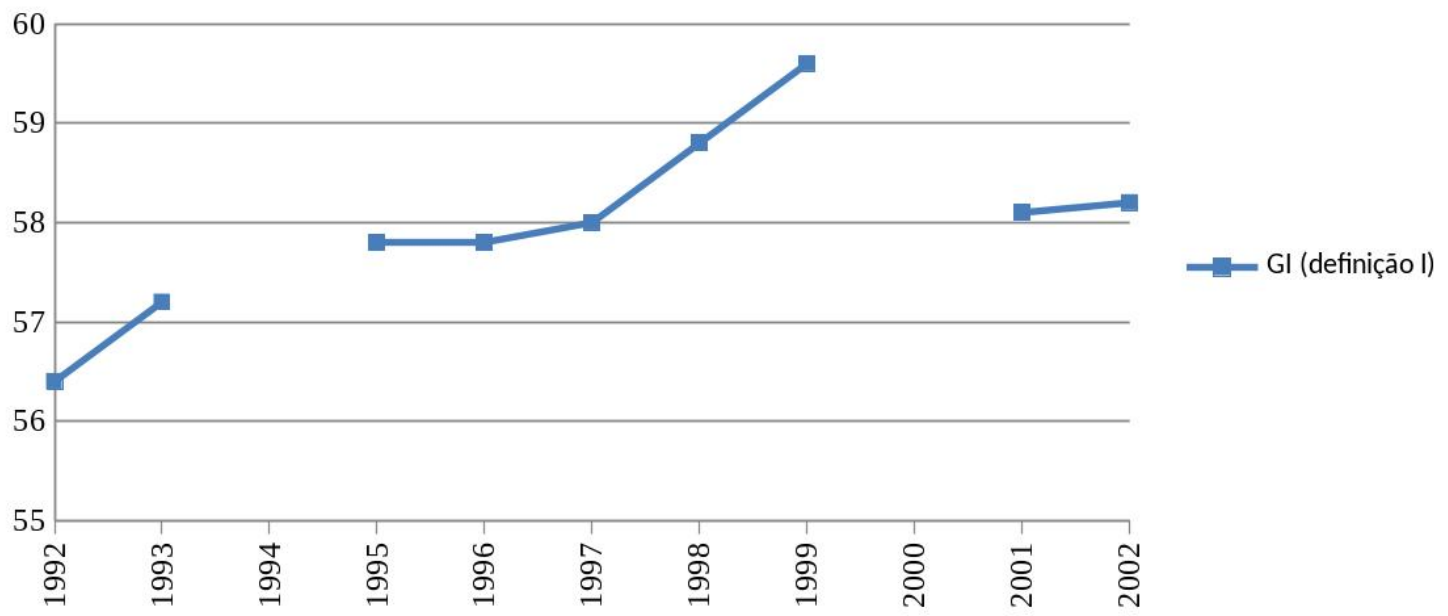

fonte: IBGE/PNAD, 2016a. Elaboração própria.

(1) Não há informações disponíveis para o interregno 1990-1992.

(2) Em 1994 e 2000 a Pesquisa Nacional por Amostra de Domicílios (PNAD) não foi realizada. Em 2000 os dados não foram calculados devido à realização do Censo Demográfico, ocasião em que a PNAD é interrompida pelo Instituto Brasileiro de Geografia e Estatística (IBGE).

cação profissional existente frente às necessidades de especialização flexível; iii) transformação de grande parcela dos empregos ditos formais em trabalho informal (sem carteira assinada, desempregos abertos, ocultos e precários), decorrentes das assertivas anteriores. Frisa-se que mesmo na década de 1980 o GI era alto. Assim foi historicamente e o é no presente, desde o primeiro embrião da instituição do assalariamento no país (ver Vargas, 2017).

Esses resultados colaboraram para as alterações das relações socioeconômicas e culturais. Em sua obra, Polanyi dá atenção especial a tais aspectos. Quanto aos impactos das alterações nas relações sociais derivadas do sistema de mercado, o autor esclarece que a condição de vida precária e indigna não se deve tão somente à vantagem recorrente de uma das partes à custa da outra nas transações econômicas estabelecidas, mas fundamentalmente porque tal sistema "afeta um grande número de hábitos sociais, costumes e tradições de todos os tipos" (POLANYI, 2012a, p. 325-326).

Ainda de acordo com Polanyi, "as civilizações, como a própria vida, resultam da interação de um grande número de fatores independentes, os quais, como regra, não se reduzem a instituições circunscritas" (POLANYI, 2012a, p. 18). Além disso, no que se refere à relação entre o sistema de mercado e o homem,

"permitir que o mecanismo de mercado seja o único dirigente do destino dos seres humanos e do seu ambiente natural, e até mesmo o árbitro da quantidade e do uso do poder de compra, resultaria no desmoronamento da sociedade. Esta suposta mercadoria, "a força de trabalho", não pode ser impelida, usada indiscriminadamente, ou até mesmo não

Econômica-Niterói, v. 19, n. 2, p. 155-180. dezembro, 2017 
utilizada, sem afetar também o indivíduo humano que acontece ser o portador dessa mercadoria peculiar. Ao dispor da força de trabalho de um homem, o sistema disporia também, incidentalmente, da entidade física, psicológica e moral do "homem" ligado a essa etiqueta. Despojados da cobertura protetora das instituições culturais, os seres humanos sucumbiriam sob os efeitos do abandono social (POLANYI, 2012a, p. 94-95)."

Houve uma mudança no modelo econômico adotado para o Brasil na década de 1990 em relação àquele construído desde 1930. Se o último estava centrado no desenvolvimento da base produtiva local e nos mercados internos, o primeiro exigiu um processo de ampla abertura comercial que expôs as forças produtivas internas abruptamente à concorrência externa, avaliada pelos policy makers da época como a única via possível para a modernização econômica (DEDECCA, 2005; FONSECA, CUNHA e BICHARA, 2013).

A desarticulação do padrão de desenvolvimento do Brasil aconteceu concomitantemente à emergência do novo padrão tecnológico e produtivo em nível global, resultado de um processo de desestruturação da "antiga" ordem econômica mundial do pós-Segunda Guerra Mundial e da crise que atingiu os países capitalistas avançados. A incorporação das TICs e de novos métodos de organização e gestão do trabalho acelerou o processo de racionalização econômica assentada na desverticalização e na emergência de sistemas de subcontratação de produtos e serviços. A terceirização constituiu-se em uma estratégia importante de diminuição dos custos do trabalho, significando a substituição de empregos regulares por empregos precários, muitas vezes sem regulamentação, informais (BETTIOL, 2009).

No que diz respeito ao panorama nacional entre 1990 e 2002, é possível traçar-se um paralelo desse com a teoria do duplo movimento. Guardadas as devidas proporções e respeitadas as especificidades históricas e institucionais de cada período, ocorreu no Brasil uma "grande transformação" nos anos noventa. Assim como Polanyi, não se nega que ao fim e ao cabo o mercado autorregulado trouxe algum nível de "riqueza material" para o conjunto da sociedade, mas acredita-se igualmente que esse fito em si ficou muito restrito ao viés econômico. Tal qual o autor diagnosticou em 1944, também aplicável ao caso brasileiro,

\footnotetext{
"a estabilização da moeda se tornara o ponto focal no pensamento político de povos e governos [...]. O pagamento dos empréstimos externos e o retorno às moedas estáveis eram reconhecidos como as pedras de toque da racionalidade política. Nenhum sofrimento particular, nenhuma violação de soberania, era considerado um sacrifício demasiado grande para a recuperação da integridade monetária. As privações dos desempregados [e também dos "informalizados"], a demissão de funcionários públicos, [...] até mesmo o abandono dos direitos nacionais e a perda das liberdades constitucionais eram considerados um preço justo a pagar pelo cumprimento da exigência de orçamentos estáveis e moedas sólidas (POLANY, 2012a, p. 174)."
} 
166 Desenvolvimento socioeconômico brasileiro entre 1990 e 2012: considerações sobre a informalidade do trabalho à luz da teoria do duplo movimento de Polanyi

A razão da existência de qualquer governo é a capacidade de resguardar seus cidadãos da insegurança. Um regime global que obstaculiza os Estados de implementar essa função protetora cria as condições para uma instabilidade política, econômica e social ainda mais aguda. O êxito das finanças globais e a diminuição da possibilidade de disciplinar política e socialmente a economia são as características mais salientes do sistema de mercado. Nesse sentido, a análise de Polanyi ajuda a explicar por que o alinhamento do Brasil à desregulamentação global do sistema de mercado na década de noventa redundou em desigualdade crescente, crises financeiras e ampliação da informalidade. A partir dessa perspectiva, o cenário nacional e seu mundo de trabalho ganharam novos tons no início do século XXI, com o "contramovimento" (parcial) que será examinado na seção seguinte.

\section{Início do século XXI em um mundo do trabalho reconfigurado: o "contramovimento"}

Como exposto na seção anterior, a economia brasileira entre 1990 e 2002 foi marcada pela estabilização monetária, abertura econômica e intensificação da flexibilização das relações trabalhistas. Já entre 2003 e 2012 consolidou-se o processo de estabilização econômica e de inserção internacional do Brasil, potencializado com a condução mais ativa do Estado em termos de políticas sociais. Na seara institucional houve medidas que indicaram tanto o aprofundamento da flexibilização quanto a perspectiva de retomada da regulação laboral. Esse cenário associado a um mundo do trabalho reconfigurado, sujeito a céleres transformações na composição das forças produtivas, favoreceu a diminuição moderada da informalidade. Todavia, o não enfrentamento de problemas crônicos nas esferas econômica e social ${ }^{11}$ continuou obstaculizando a diminuição mais efetiva e sólida do trabalho informal.

A performance da economia brasileira nesse período foi decisivamente influenciada pela evolução da economia internacional. Os resultados do nível de atividade e do comportamento dos preços foram positivos. Entre 2003 e 2008 a taxa média de crescimento do produto interno bruto no Brasil foi de 4,21\% (4,25\% mundialmente), enquanto que entre 2009 e 2012 foi de 2,74\% (2,76\% mundialmente) (IBGE/SCN, 2016). A inflação apresentou patamar menor quando comparada às taxas médias observadas nos períodos anteriores, evidenciando junto a outros indicadores a consolidação do processo de estabilização econômica. Entre 2003 e 2012 a taxa média de inflação foi de 5,86\%, o que retroalimentou o otimismo com relação à evolução da economia brasileira (IBGE/SNIPC, 2016).

\footnotetext{
${ }^{11}$ Basta lembrar que apesar de estar no piso das séries históricas mensuradas desde o censo de 1960, a desigualdade brasileira figura entre as doze mais altas do mundo (CHAHAD e POZZO, 2013b). Outras importantes questões históricas por resolver e que assolam a economia e a sociedade brasileira, do ponto de vista do autor, são a alta concentração de renda e a pobreza (extrema), havendo relações estreitas destas com a informalidade do trabalho.
}

Econômica-Niterói, v. 19, n. 2, p. 155-180. dezembro, 2017 
Assim, como justificativas para os avanços sociais no período mantiveram-se, conforme Fonseca, Cunha e Bichara (2013, p. 408-409),

\begin{abstract}
"não só alguns marcos essenciais da política econômica em prol da estabilidade do governo Fernando Henrique Cardoso (metas de inflação, taxa de câmbio flexível e valorizada, superávit primário), mas ampliou vários programas de assistência social. A implementação das teses de focalização das políticas sociais iniciadas por este último, críticas à universalização dos direitos, [...] graças a essa expansão ganhou um status de quase universalidade: só o Programa Bolsa-Família foi estendido a 11 milhões de famílias ${ }^{12}$, quase triplicando sua abrangência."
\end{abstract}

Essa gestão baseada nas transferências diretas aos indivíduos - mais intenso a partir de meados da década - implicou em estímulo ao consumo, especialmente em um contexto marcado pela baixa inflação. Cabe ressaltar que esse período traduziu-se no surgimento de uma nova percepção - interna e externa - acerca do novo papel do Brasil no mundo, em que, segundo Giambiagi et al (2011), houve fatores que se combinaram, tais como: a crescente importância da China no mundo, a avidez das economias emergentes por produtos dos quais o Brasil tornara-se grande produtor, as potencialidades associadas à exploração do etanol, as descobertas de petróleo do pré-sal, os efeitos indiretos da crise de 2009 sobre a imagem do país e a escolha do país para ser sede da Copa do Mundo de 2014 e das Olimpíadas de 2016.

Sucintamente, pode-se afirmar que nesse período existiu continuidade do regime de política econômica implementado desde o início dos anos noventa, aderindo-se, portanto, ao modelo de especialização flexível. Todavia, comparativamente, houve maior regulação e participação do Estado, especialmente na questão social. Com efeito, relegou-se a um segundo plano a função de Estado empresário que vigorou até o final dos anos oitenta e abandonou-se a visão anti-mercado que seduzia alguns segmentos nacionais (BARBOSA, 2008).

Nesse ínterim podem-se estabelecer alguns nexos de convergência entre a política econômica implementada entre 1990 e 2012 (e seus efeitos sobre a economia brasileira) e a teoria polanyiana. Se entre 1990 e 2002 o Brasil assistiu a uma espécie de "grande transformação", entre 2003 e 2012 pode-se aventar a possibilidade de ter-se ao menos ensaiado "alguns contramovimentos protetores que cercearam a ação desse mecanismo" (POLANYI, 2012a, p. 98). Abre-se também a possibilidade de discussão sobre até que ponto essa eventual guinada de rumos (mais sensível às demandas sociais) foi espontânea, visto que o autor diagnosticou para o período que estudava que

\footnotetext{
12“O Bolsa Família é um programa de transferência direta de renda que beneficia famílias em situação de pobreza e de extrema pobreza em todo o país. O Bolsa Família integra o Plano Brasil Sem Miséria, que tem como foco de atuação os milhões de brasileiros com renda familiar per capita inferior a R \$ 77 mensais e está baseado na garantia de renda, inclusão produtiva e no acesso aos serviços públicos (BRASIL, 2016)." O programa foi instituído pela Lei 10.836/2004 e regulamentado pelo Decreto $\mathrm{n}^{\circ}$ 5.209/2004. Atendeu onze milhões de famílias em 2010 e quase quatorze milhões em 2013. Ver IPEA (2013).
} 
168 Desenvolvimento socioeconômico brasileiro entre 1990 e 2012: considerações sobre a informalidade do trabalho à luz da teoria do duplo movimento de Polanyi

\begin{abstract}
"a grande variedade de formas nas quais surgiu o contramovimento "coletivista" [entre o final do século XIX e meados do século XX] não foi devida a qualquer preferência pelo socialismo ou pelo nacionalismo por parte dos interesses envolvidos, mas deveu-se exclusivamente ao alcance mais amplo dos interesses sociais vitais afetados pela expansão do mecanismo de mercado (POLANYI, 2012a, p. 178)."
\end{abstract}

Outra analogia possível a partir do pensamento de Polanyi faz-se pertinente. O país, dadas às circunstâncias internas e o estágio avançado da globalização ainda em pleno curso, não poderia (e nem era o caso) de reverter totalmente os resultados de mais de uma década de políticas econômicas pró-sistema de mercado. Ao mesmo tempo, a maioria dos cidadãos brasileiros acenou democraticamente (via eleições gerais) com seu desejo de maior proteção do Estado e de voz ativa para a sociedade civil nos desígnios da nação, buscando retomar e avançar na instituição de um Estado de bem-estar social, conforme prevê o core da CF/88. Assim, buscou-se caminhar rumo a um Estado regulador e de bemestar social. Nas palavras do pensador austríaco, "essas medidas comprovam a natureza puramente prática, pragmática, do contramovimento 'coletivista'" (POLANYI, 2012a, p. 178).

Assim sendo, tem-se que as oscilações do GI estiveram diretamente vinculadas ao comportamento da economia brasileira. Se nos anos 1980 ela permaneceu estável em função de não haver grandes mudanças estruturais, com a movimentação em direção ao sistema de mercado nos anos 1990 ocorreu, pari passu, sua elevação a níveis alarmantes e jamais vistos na história do país. Na medida em que houve o "contramovimento" nos anos 2000, ela retornou aos níveis históricos de 1980. Cumpre frisar que, a despeito das flutuações para cima e para baixo ao longo do recorte temporal analisado, a informalidade desde o surgimento do mercado de trabalho no Brasil ${ }^{13}$ se constituiu em um dos problemas mais nevrálgicos e sem resolução do mundo de trabalho. Com isso, vê-se que a questão da informalidade extrapola a esfera econômica e transborda para o campo institucional e social, sendo uma questão que obstaculiza o desenvolvimento socioeconômico. É mister apontar sua raiz mais profunda.

Institucionalmente, no início do século XXI o Estado emitiu sinais contraditórios: algumas medidas flexibilizadoras e outras aumentando a regulação laboral. No primeiro caso, a agenda persistiu e espraiou-se em alguns pontos, tais como o aumento da jornada de trabalho, a elevação da taxa de rotatividade, a ampliação da contratação atípica e da prática da remuneração variável. A flexibilização pós 2002 não foi concebida genericamente, mas sim para públicos específicos (sobretudo pessoa jurídica, jovens, micro e pequenas empresas) e foram implementadas através de alterações institucionais focais das relações de trabalho (KREIN, SANTOS e NUNES, 2011).

Dentre as medidas flexibilizadoras, destacou-se a reforma previdenciária. Encami-

\footnotetext{
${ }^{13}$ Resultante da transição do sistema escravista para o assalariamento, compreendido entre o final do século XIX e o final da década de 1920. A Lei Áurea foi seu marco cronológico. Ver Vargas (2017).
}

Econômica-Niterói, v. 19, n. 2, p. 155-180. dezembro, 2017 
nhada e aprovada em 2003 sob a condução do Governo Federal, contou com o empenho e a utilização decisiva dos recursos políticos e institucionais disponíveis. Constata-se o aprofundamento da posição adotada no fim do século XX. Essa perda de direitos influenciou na interpretação dos agentes econômicos quanto à atuação do governo na questão trabalhista, sobretudo no âmbito do Fórum Nacional do Trabalho ${ }^{14}$ (DAL MOLIN, 2012).

Quanto à retomada da regulação pública do mercado de trabalho, merecem destaque no pós 2002 a valorização do salário mínimo, a ampliação do seguro-desemprego no ápice da crise de 2008 e 2009, a nova regulamentação do estágio e o estímulo para inclusão do autônomo na seguridade social (KREIN, SANTOS e NUNES, 2011). A medida mais abrangente nesse sentido foi a política do salário mínimo. Criou-se um critério concreto de valorização real dos rendimentos, favorecendo a regulação pública da remuneração, que se mantida ao longo do tempo - desde que combinada com outros mecanismos apoia o crescimento dos salários das categorias de trabalhadores menos organizados, ao mesmo tempo em que favorece a negociação das demais categorias. O salário mínimo real que era de $\mathrm{R} \$ 560,88$ no mês de junho 2005 passou para $\mathrm{R} \$ 871,50$ em janeiro de 2014 (valores constantes de dezembro de 2008, deflacionados pelo INPC) (IPEA, 2016).

$\mathrm{Na}$ discussão sobre o arranjo institucional e suas alterações para compatibilizarem-se ao contexto socioeconômico vigente, os escritos de Polanyi mostram-se úteis para analisar a questão dos rendimentos reais na década de 2000 no Brasil. No que toca rendimentos e liberdades, o autor diz que:

"Em nível institucional, a regulação tanto amplia como restringe a liberdade; só é significativo o equilíbrio das liberdades perdidas e recuperadas. Isto é verdade tanto em relação às liberdades jurídicas como às liberdades reais. As classes abastadas gozam da liberdade que lhes oferece o ócio em segurança; elas estão naturalmente menos propensas a ampliar a liberdade na sociedade do que aquelas que, por falta de rendas, têm que se contentar com um mínimo de liberdade. Isto é perfeitamente visível quando surge uma compulsão no sentido de uma distribuição mais justa da renda, do lazer e da segurança. Embora as restrições se apliquem a todos, os privilegiados tendem a ressentir-se, como se elas fossem dirigidas apenas contra eles. Eles falam em escravidão quando de fato se pretende apenas distribuir entre outros a liberdade de que eles mesmos gozam. É verdade que pode ocorrer inicialmente uma diminuição do seu lazer e da sua segurança e, portanto, da sua liberdade, para que seja elevado o nível de liberdade para todos. Todavia, uma tal mudança, a remodelação e a ampliação das liberdades, não deve servir de motivo para que se afirme que a nova situação é, necessariamente, menos livre do que a anterior. (POLANYI, 2012a, p. 295)."

Note-se que o balanço institucional desse período é, portanto, ambíguo. O ambiente

\footnotetext{
${ }^{14}$ O Fórum Nacional do Trabalho foi criado em 2003 com a finalidade de coordenar a negociação entre os representantes dos trabalhadores, empregadores e Governo Federal sobre a reforma sindical e trabalhista no Brasil. Ver BRASIL (2004, 2005) e Dal Molin (2012).
} 
econômico favorável contribuiu para diminuir a pressão do movimento de flexibilização do trabalho. As medidas pontuais indicaram oscilação entre flexibilização e medidas de ampliação da regulação pública. Todavia, exceção feita à política de valorização do salário mínimo no último caso, não houve nenhuma medida de maior impacto.

Já o desempenho do mercado nacional de trabalho foi positivo no interregno 20032012. Assistiu-se a melhora de seus principais indicadores, como a diminuição da informalidade. Todavia, também é verdade que ele fragmentou-se, heterogeneizou-se e complexificou-se ainda mais em relação às duas últimas décadas do século $\mathrm{XX}$, com que se tem na atualidade um mundo do trabalho reconfigurado. De um lado, há o "trabalhador polivalente e multifuncional", e de outro, uma "massa precarizada sem qualificação". Logo, a questão do "novo" mercado de trabalho impõe desafios ao país, sendo um dos "mais urgentes e graves problemas políticos e sociais na contemporaneidade" (ATAÍDE, 2012, p. 338-339).

O otimismo com a evolução econômica intensificou a demanda e a oferta de trabalho formal, o que resultou em queda da informalidade, representando expressivos contingentes de trabalhadores demitidos e admitidos - no que se refere aos vínculos celetistas - em termos líquidos mensais. O aumento da rotatividade da mão de obra - entendida como a substituição de um trabalhador por outro no mesmo posto de trabalho - se deu muito em função do desligamento a pedido do empregado que, via de regra, procurou aumentos salariais. É verdade também que esse movimento deixou um contingente maior de trabalhadores mais suscetíveis a serem dispensados. Destaca-se o fato dela ter ocorrido especialmente entre as ocupações de baixa remuneração e qualificação profissional, a despeito de se estar demandando mão de obra mais escolarizada (IBARRA, 2013, p. 254; MTE/RAIS, 2015).

Outra situação que dificulta a diminuição mais efetiva do GI no Brasil é a celebração expressiva de "contratos atípicos de trabalho" (alheios à regulação laboral) ${ }^{15}$. Esse em tese alcança a rede de proteção do trabalhador, como o "princípio da continuidade do trabalho", impingindo-o a ocupações precárias, interinas e informais. É o contrário de um acordo estabelecido entre o empregado e o empregador, que pelo fato de ser estável favorece a permanência do primeiro por prazo mais longo, possibilitando-lhe a "concretização da carreira e a ascensão profissional" (DIAS e SANSON, 2014, p. 180). Esse é um desafio institucional importante, pois há tendência de aumento dessa prática, deixando paulatinamente os vínculos formais de trabalho mais frágeis (vide o caso da terceirização, por exemplo).

No que diz respeito especificamente ao grau de informalidade no mercado nacional de

\footnotetext{
${ }^{15}$ Inexiste definição internacional oficial para trabalho atípico. Todavia, a International Labour Organization (ILO, 2016) atenta para o fato de que comumente se enquadram nesta categoria as atividades exercidas em jornada parcial; temporária; com contratos zero horas, cujo mínimo de horas não é garantido ao funcionário; sem relação formal de emprego e congêneres - podendo facilitar o acesso do cidadão ao mercado de trabalho (mormente precário) e oferecer flexibilidade, especialmente para o contratante. Dessa forma, vem sendo uma opção amplamente adotada por empresas que buscam reduzir custos.
}

Econômica-Niterói, v. 19, n. 2, p. 155-180. dezembro, 2017 
trabalho, observa-se no gráfico 2 que entre 2003 e 2012 sua diminuição foi progressiva, sendo importante destacar que, mesmo com estas novas modalidades de trabalho, o total de ocupações com registro formal de carteira de trabalho assinada cresceu substancialmente. Entretanto, manteve-se acima de $50 \%$ até o ano de 2009, sendo o pico da série registrado no ano de $2003(57,4 \%)$. Já o menor valor registrado corresponde a 47\%, em 2012 .

Gráfico 2 - Grau de informalidade (\%) - Brasil (2003-2012)

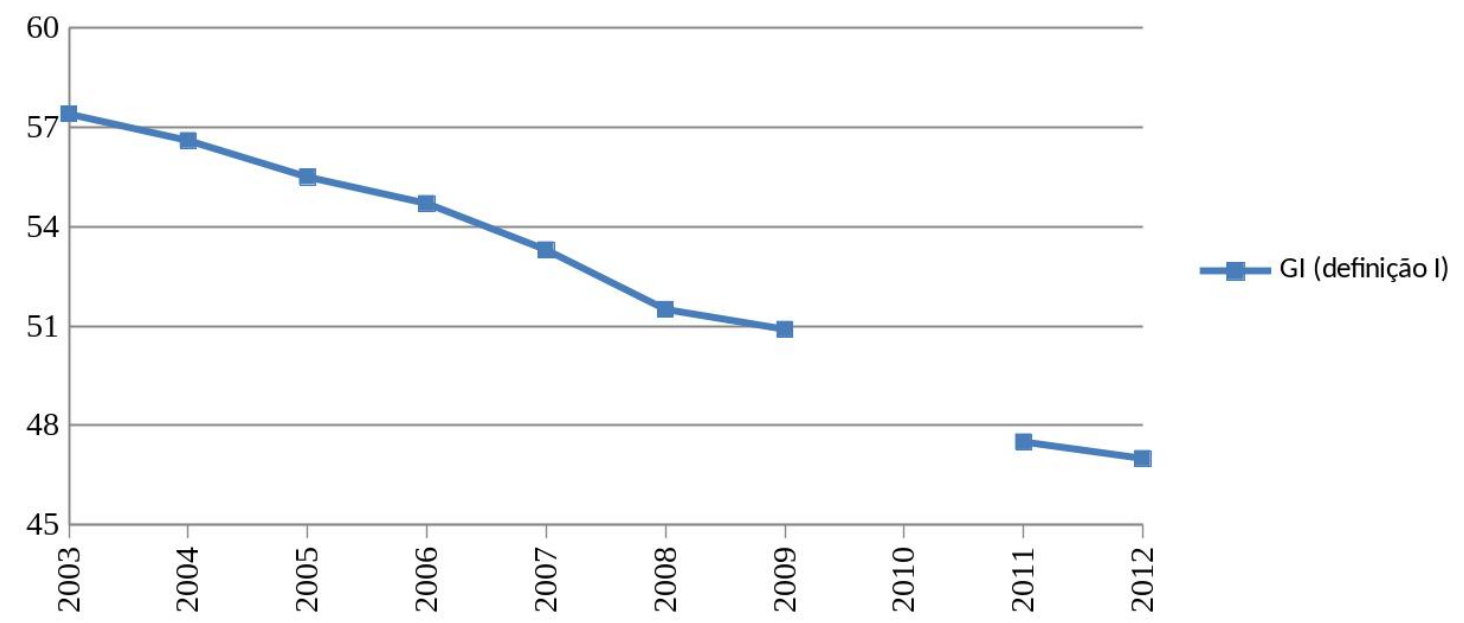

Fonte: IBGE/PNAD, 2016a. Elaboração própria. Nota: A PNAD não foi realizada no ano de 2010, já que os dados não são calculados para os anos de elaboração do Censo Demográfico, quando a série é interrompida pelo IBGE.

(1) Não há informações disponíveis para o interregno 1990-1992.

(2) Em 1994 e 2000 a Pesquisa Nacional por Amostra de Domicílios (PNAD) não foi realizada. Em 2000 os dados não foram calculados devido à realização do Censo Demográfico, ocasião em que a PNAD é interrompida pelo Instituto Brasileiro de Geografia e Estatística (IBGE).

Atenta-se para o fato de que a queda verificada em 2012 ante o ano de 2003 deu-se tanto em termos relativos (percentuais) quanto em termos absolutos, mesmo considerandose o crescente número de entrantes no mercado de trabalho. Em termos absolutos, o número de pessoas que saiu da condição informal entremeios representou mais de quatro milhões e cem mil trabalhadores, apontando forte tendência de que um contingente expressivo da população economicamente ativa (PEA) brasileira formalizou-se ano após ano. Ressalta-se que há que se considerar outros fatores (além do ambiente econômico favorável) que podem ter influenciado na diminuição mais vigorosa do GI nesse período, como a mudança metodológica de cálculo (passando de dez para quinze anos de idade e excluindo certas categorias de trabalhadores, por exemplo), a entrada mais tardia no mundo do trabalho (motivado pelo maior número de anos de estudo ${ }^{16}$, por exemplo), den-

\footnotetext{
${ }^{16}$ Segundo o IBGE/PNAD (2016b), a média total de anos de estudo da população residente total (com quinze anos ou mais no Brasil) foi de 6.53 anos em 2002, 7.25 anos em 2007 e 7.88 em 2012, representando um aumento médio de mais de um ano de educação formal no período. Esses estudantes figuram então na população em idade ativa (PIA), e não na PEA.
} 
172 Desenvolvimento socioeconômico brasileiro entre 1990 e 2012: considerações sobre a informalidade do trabalho à luz da teoria do duplo movimento de Polanyi

tre outros.

Deve-se ponderar por que a informalidade cresceu até o fim da década de 1990 e apresentou trajetória de queda moderada desde então. Segundo Chahad e Pozzo (2013a) e Cardoso Jr. (2002, p. 107), pode-se identificar ao menos oito fatores explicativos para a dinâmica recente de assalariamento formal do mercado de trabalho brasileiro, "todos eles operando numa mesma direção, provavelmente em simultâneo, ainda que em combinações diversas entre si”. São eles:

I) estabilidade econômica, o que permitiu ao setor produtivo fazer planejamento econômico;

II) aumento e desconcentração do gasto social;

III) aumento e diversificação do crédito interno;

IV) aumento e diversificação da pauta de exportações;

v) consolidação do regime tributário simplificado para microempresas e empresas de pequeno porte, estimulando a formalização das empresas;

VI) maior eficácia das ações de intermediação de mão de obra e de fiscalização das relações e condições de trabalho nas empresas;

VII) aumento da qualificação (educação formal e técnica) dos trabalhadores, apesar das múltiplas carências ainda existentes em todos os níveis do sistema educacional.

VIII) bônus demográfico ${ }^{17}$.

Cabe salientar que, embora se reconheçam progressos expressivos no mercado de trabalho brasileiro, não se verifica mudança substancial na estrutura ocupacional do país quanto à complexidade, à heterogeneidade e à precarização. As alterações que favoreceram a diminuição do GI são, em geral, conjunturais. Os setores de maior geração de postos de trabalho foram aqueles tradicionalmente caracterizados pelos baixos salários (serviços e comércio), sendo que cerca de $90 \%$ das ocupações criadas na última década foram de até 1,5 salários mínimos (ver Neri, 2012).

Todavia, há ainda um enorme contingente da população brasileira atuando na informalidade, alijados do sistema de proteção social e de uma série de direitos trabalhistas e sociais previstos em leis. Basta observar que a proporção média observada no mercado nacional de trabalho é da ordem de um trabalhador informal para cada trabalhador formal (gráficos 1 e 2), o que é absolutamente inconcebível sob qualquer parâmetro. Além disso, ressalta-se uma vez mais o fato de que mesmo com mais de uma década de quedas consecutivas do GI no Brasil, os resultados alcançados são tão insatisfatórios quanto os

\footnotetext{
${ }^{17} \mathrm{O}$ bônus demográfico ocorre quando o quadro populacional apresenta elementos fortemente positivos favorecendo o crescimento econômico. Representa uma "janela de oportunidades” originada pelas transformações na estrutura etária da população. Essas mudanças decorrem da transição demográfica pela qual um país passa e pode se beneficiar uma única vez (CHAHAD e POZZO, 2013a). Ver também Alves (2010).
}

Econômica-Niterói, v. 19, n. 2, p. 155-180. dezembro, 2017 
existentes nos anos 1980. Por que isso ocorre? A resposta transpassa pela concepção teórica polanyiana, do reconhecimento de que os indivíduos e suas relações encontram-se imersos em instituições culturais historicamente constituídas que os condicionam, isto é, em seus hábitos socialmente incrustados.

O pensador austríaco chama a atenção para o fato de que a justiça social deve ser o maior "contramovimento" face à "grande transformação". Para isso ocorrer de forma prática é necessário o "reincrustamento" (re-embeddedness) social da economia. Isso significa que o bem-estar social deve ser construído democraticamente com a participação ativa do Estado e da sociedade civil, sem a necessidade de negar a presença e a importância dos mercados. Assim, a concepção de justiça social de Polanyi ressalta dois aspectos fundamentais: i) o significado da existência humana; ii) a reflexão em torno das conexões entre a economia e a dignidade dos seres humanos (POLANYI, 2012a). Ambos apontam um caminho profícuo para repensar a questão da informalidade histórica verificada no Brasil.

O autor ainda destaca que se isso não puder ser realizado pela via democrática, pode abrir brechas tentadoras para o autoritarismo como fio condutor da sociedade (a ascensão do totalitarismo na década de 1930 foi um exemplo de contramovimento que, ao reconhecer a realidade da sociedade, rejeitou o postulado da liberdade). Para o autor, a manutenção de certas liberdades é essencial e devemos "prezá-las por elas mesmas". Separar institucionalmente o político do econômico é danoso para a sociedade e sua tentativa leva a uma "falsa liberdade à custa da justiça e da segurança das pessoas". Não se deve separar a liberdade jurídica da real, pois ao fazê-lo estimula-se "o desemprego [a informalidade] e os lucros do especulador" (POLANYI, 2012a, p. 295). Nas palavras de Polanyi (2012a, p. 301),

\footnotetext{
"a aceitação, sem queixas, da realidade da sociedade dá ao homem uma coragem indômita e forças para afastar todas as injustiças e a falta de liberdade que podem ser eliminadas. Enquanto ele se conservar fiel à sua tarefa de criar uma liberdade mais ampla para todos, ele não precisa temer que o poder ou o planejamento se voltem contra ele e que destruam, através da sua instrumentalidade, a liberdade que ele está construindo. Este é o significado da liberdade numa sociedade complexa e ele nos dá toda a certeza de que precisamos."
}

Aplicando ao contexto brasileiro, deve-se encarar a informalidade como a concretização da precariedade da própria existência humana, em todos os níveis. Essa é a condição sine qua non para que seja possível libertar-se dela em termos tanto individuais quanto sociais. Isso implica em quebrar os hábitos enraizados desde há muito no core dos brasileiros, tarefa hercúlea diante das idiossincrasias nacionais, mas que ao ser efetivada por certo ampliará as liberdades para o conjunto da sociedade brasileira.

Desde o surgimento do mercado de trabalho no Brasil a informalidade permaneceu em patamares bastante elevados, isto é, sua raiz é a desigualdade social histórica da sociedade brasileira. Por isso, independentemente de maior ou menor participação do Estado, 
174 Desenvolvimento socioeconômico brasileiro entre 1990 e 2012: considerações sobre a informalidade do trabalho à luz da teoria do duplo movimento de Polanyi

existência ou não de crises econômicas, seja antes, seja depois da promulgação da CF/88 e da instituição do bem-estar social, presença ou não das TICs, inter alia, o GI no país sempre foi muito elevado. Essas variáveis apenas implicaram em pequenas - embora às vezes significativas - alterações das composições e dos níveis de informalidade, longe de serem suficientes para sanar efetivamente a questão.

Em vista disso, uma conclusão presumível é a de que a informalidade é um hábito incrustrado nos diversos agentes, isto é, antes de ter-se um mercado nacional de trabalho com um alto grau de informalidade, tem-se uma sociedade brasileira altamente informal. A instituição "trabalho informal" persiste mesmo quando há mudanças de ordem socioeconômica. Parafraseando o argumento de Polanyi apresentado para a economia, a informalidade está incrustada na sociedade brasileira. Resta então fazer o caminho inverso ao prescrito para a economia e "desincrustrar" a informalidade dessa sociedade.

Esse parece ser o caminho a ser trilhado para superar efetivamente o problema da informalidade. Maior efetividade das leis e aprimoramentos institucionais acompanhados de coordenação e "vontade política" devem ser os fios condutores desse processo. Isso alicerçado pela tomada de consciência crescente da sociedade civil quanto à importância da formalização e aos males da informalidade do trabalho tanto para seus cidadãos quanto para a nação.

Ressalta-se que, de fato, ocorreram avanços importantes no mercado nacional de trabalho pós 2000, especialmente no que se refere à diminuição da informalidade até 2013. Todavia, frisa-se igualmente que as celebrações por parte do poder público dessa retomada, sobretudo dos empregos com carteira assinada a partir de 2002, "ainda que positivas, mais se assemelham a retóricas ante o enorme déficit nos números da inserção econômica e social historicamente registrados no país". Há correlação positiva estreita entre a solidez do crescimento econômico e a diminuição do GI. Mas esse crescimento parece não guardar essa correlação com o nível de emprego que registrou em outros períodos (COSTA, 2010, p. 16).

Face ao aprofundamento dos processos relativos à globalização tendem a aumentar as taxas de crescimento da produção, porém, sem aumento correspondente e suficiente de empregos formais. Além disso, uma vez que o problema do emprego foi sistematicamente acomodado na informalidade, essa exclusão econômica e social histórica é um claro sinal de ausência de brechas no mercado de trabalho, as quais possam acomodar aqueles que não conseguem um emprego protegido (DEDECCA, 2005).

Em suma, ao negligenciar problemas socioeconômicos crônicos impediu-se a redução mais sólida do problema da informalidade. Sua solução passa por encará-la como a precarização da própria existência humana, condição essencial para suplantá-la. 


\section{Considerações finais}

A finalidade dessa pesquisa foi a de examinar os nexos de convergência entre o desenvolvimento socioeconômico e a evolução da informalidade no mercado nacional de trabalho no interregno 1990-2012, à luz da teoria do duplo movimento de Polanyi. Podese afirmar que as contribuições teóricas desse autor permitiram criar um instrumental de análise adequado ao estudo proposto, na medida em que possibilitaram perscrutar diversos aspectos concernentes à informalidade do trabalho.

Demonstrou-se como se engendrou, no interregno 1990-2002, o aprofundamento do processo de abertura e desregulamentação dos mercados na economia brasileira. Também foi analisado como as sucessivas crises econômicas e as alterações institucionais promovidas visando superá-las afetaram as estruturas do mundo do trabalho, flexibilizando as relações trabalhistas e a conformação do mercado nacional de trabalho. O aumento urbi et orbi do fenômeno da informalidade foi um de seus resultados mais visíveis.

Nesse período o Estado brasileiro voltou-se à estabilização interna e a inserção internacional, sob um conjunto de políticas pautadas pela nova ordem econômica mundial, a fim de superar os entraves ao crescimento. Isso impactou a dinâmica institucional, provocando a redefinição do papel do Estado e a flexibilização da legislação trabalhista. Assim, assevera-se que os acontecimentos do período divergiram da proposta desenvolvida por Polanyi a respeito do desenvolvimento socioeconômico. Pode-se por analogia afirmar que nessa década o Brasil sofreu sua "grande transformação".

Entre 2003 e 2012 consolidou-se o processo de estabilização econômica e de inserção internacional do Brasil, associados a avanços sociais significativos e a atuação mais ativa do Estado. Na seara institucional o balanço foi ambíguo, com alterações tanto voltadas ao aprofundamento da flexibilização quanto à retomada da regulação laboral. Essa dinâmica interagiu com um mundo do trabalho reconfigurado, favorecendo a diminuição moderada do GI. Entretanto, ao negligenciar problemas socioeconômicos crônicos impediu-se uma redução mais sólida da informalidade. O Brasil não mais que ensaiou um "contramovimento" (a là Polanyi) rumo a um Estado regulador e de bem-estar social. Evidenciou-se, assim, que a questão da informalidade extrapola a esfera econômica e transborda para o campo institucional e social, consistindo em um entrave ao desenvolvimento socioeconômico.

Conclui-se que, para além de sugerir o diálogo a respeito de possíveis aprimoramentos dos arranjos institucionais em geral e especificamente dos que regem o mercado de trabalho, a sociedade brasileira ambiciona avanços, o que exigirá concretamente uma mudança de hábitos há muito enraizados, no sentido de não consentir com a alta informalidade do trabalho verificada. Tem-se ciência de que questões relativas ao mercado de trabalho são complexas, especialmente por envolver interesses divergentes. Assim, não pode ser encarado tão somente como um mercado convencional que é reduzido a um sistema de preço concorrencial de alocação de recursos escassos, produzindo a partir de uma minimização 
176 Desenvolvimento socioeconômico brasileiro entre 1990 e 2012: considerações sobre a informalidade do trabalho à luz da teoria do duplo movimento de Polanyi

dos custos e assim alcançando um estado de ótimo social, como comumente é o enfoque tradicional.

Uma abordagem sistêmica permite incluir importantes elementos ao debate, tornando as análises socioeconômicas mais robustas e realistas, o que é uma necessidade frente aos desafios atuais. A teoria do duplo movimento é valorosa nesse sentido, não negando a relevância dos mercados, mas enfatizando a primazia da sociedade e de suas instituições como fios condutores do processo de desenvolvimento socioeconômico, promovendo a proteção do tecido social e a garantia dos direitos individuais e coletivos do trabalho. Nesse momento, em que paira iminente a ameaça de uma nova era da precarização do trabalho no mundo em geral e no Brasil em particular, atente-se, pois, para os escritos de Polanyi como alternativa para a superação desse desafio histórico!

\begin{abstract}
This study examines the nexus of convergence between socioeconomic development and the evolution of informality in the national labor market in the interregnum 1990-2012, in the light of the theory of double movement from Polanyi. Two phases are essential to the desired discussion: a) the end of the twentieth century, in which Brazil has undergone renovations that resulted in the increase in informality in the labor market; b) early twenty-first century, with renewed political participation of the state and civil society, which generated moderate decline in informal work. The double movement of Polanyian design is shown as a useful tool for understanding the first "great transformation" and as a result also to understand the "countermovement" (partial), both recorded in the country after 1990. It was concluded that the way to mitigate the historically high informality in Brazil moves through the disembeddedness of this rooted habit of the society in general.
\end{abstract}

Keywords: Brazilian Development. Informal Work. Polanyi.

JEL: J46, J82, N46.

\title{
Referências bibliográficas
}

ALVES, J. E. D. Bônus Demográfico, Crescimento Econômico e Redução da Pobreza no Brasil. Aparte Inclusão Social em Debate, Rio de Janeiro, p. 1-5, 2010. [Online; accesso 24-Março-2016]. Disponível em: <http://www.ie.ufrj.br/aparte/pdfs/bonus\_economial _el_pobreza.pdf>.

ATAIDE, M. A. O Mundo do Trabalho no Brasil a partir da década de 90: uma questão em análise. Métis: História \& Cultura, v. 11, n. 22, jul-dez, 2012.

Econômica-Niterói, v. 19, n. 2, p. 155-180. dezembro, 2017 
BARBOSA, A. de F. A formação do mercado de trabalho no Brasil. [S.1.]: São Paulo: Alameda Editorial, 2008.

BETTIOL, T. M. A informalidade do trabalho no Brasil dentro da perspectiva histórica. In: Congresso Internacional de História, n.4, Maringá. [S.1.: s.n.], 2009.

BRASIL. Fórum Nacional do Trabalho. Ministério do Trabalho e Emprego. Reforma Sindical - Relatório Final. Brasília: Brasil, 2004.

BRASIL. Fórum Nacional do Trabalho. Reforma Sindical - Proposta de Emenda à Constituição, PEC 369, Anteprojeto de Lei. Brasília: Brasil, 2005.

BRASIL. Constituição [1988]. Constituição da República Federativa do Brasil (CF/88). São Paulo: Saraiva, 44a.ed, 2010.

BRASIL. Taxa de Rotatividade Global e Descontada (\%) - Brasil (2002-2013). Brasília: MTE/RAIS, 2015. [Online; accesso 13-Abril-2018]. Disponível em: $<$ http://portal.mte.gov.br/rais/>.

BRASIL. Ministério do Desenvolvimento Social (MDS). Bolsa Família. Brasília: Brasil, 2016. [Online; accesso 23-Março-2016]. Disponível em: <http://www.mds.gov.br/ bolsafamilia>.

CARDOSO, J. C. Reforma do Estado e desregulamentação do trabalho no Brasil, nos anos 90. Ensaios FEE, v. 23, n. 2, p. 899-922, 2002.

CHADAD, J. P. Z.; POZZO, R. G. Mercado de trabalho no Brasil na primeira década do Século XXI: evolução, mudanças e perspectivas-desemprego, salários e produtividade do trabalho. São Paulo: Informações FIPE, p. 11-29, $2013 \mathrm{~b}$.

CHAHAD, J. P. Z.; POZZO, R. G. Mercado de trabalho no Brasil na primeira década do Século XXI: evolução, mudanças e perspectivas: demografia, força de trabalho e ocupação. São Paulo: Informações FIPE, p. 13-32, maio $2013 \mathrm{a}$.

COSTA, M. da S. Trabalho informal: um problema estrutural básico no entendimento das desigualdades na sociedade brasileira. Caderno CRH, Salvador, v. 23, n. 58, p. 171-190, abril 2010.

DALMOLIN, N. O Fórum Nacional do Trabalho e as Centrais Sindicais Brasileiras. Revista Latino-Americana de História, v. 1, n. 3, p. 391-406, 2012.

DEDECCA, C. S. Notas sobre a Evolução do Mercado de Trabalho no Brasil. Revista de Economia Política, v. 25, n. 1, p. 94-111, jan-mar, 2005.

DIAS, A. P.; SANSON, C. A atual estrutura ocupacional e o papel dos sindicatos no Brasil: análise do século XXI. Revista de Ciências Sociais, n. 41, p. 175-188, out 2014. 
178 Desenvolvimento socioeconômico brasileiro entre 1990 e 2012: considerações sobre a informalidade do trabalho à luz da teoria do duplo movimento de Polanyi

FONSECA, P. C. D.; CUNHA, A. M.; BICHARA, J. d. S. O Brasil na Era Lula: retorno ao desenvolvimentismo? Nova Economia, UFMG, v. 23, n. 2, p. 403-428, maio-ago 2013.

GIAMBIAGI, F.; VILLELA, A.; BARROS L C; HERMANN, J. Economia Brasileira Contemporânea (1945/2004). In: GIAMBIAGI, F. e. o. a. (Ed.). [S.1.]: Rio de Janeiro: Editora Campus, 2005.

IBARRA, A. Mercado de Trabalho Brasileiro: identificação dos problemas e propostas de enfrentamento na perspectiva da agenda social-desenvolvimentista. In: FONSECA A. E FAGNANI, E. (Ed.). Políticas sociais, desenvolvimento e cidadania: economia, distribuição da renda e mercado de trabalho. [S.l.]: São Paulo: Fundação Perseu Abramo, 2013.

IBGE. Média de anos de estudo da população residente total, com 15 anos ou mais de idade (1995-2012). [S.1.], 2016. [Online; accesso 24-Março-2016]. Disponível em: $<$ http://www.ibge.gov.br>.

IBGE. PESQUISA NACIONAL POR AMOSTRA DE DOMICÍLIOS (IBGE/PNAD). Grau de informalidade. [S.1.], 2016. [Online; accesso 19-Março-2016]. Disponível em: $<$ http://www.ibge.gov.br>.

IBGE. SISTEMA DE CONTAS NACIONAIS (IBGE/SCN). Produto Interno Bruto (PIB). [S.1.], 2016. [Online; accesso 20-Março-2016]. Disponível em: $<$ http://www.ibge.gov.br>.

IBGE. SISTEMA NACIONAL DE ÍNDICES DE PREÇOS AO CONSUMIDOR (IBGE/SNIPC). Inflação: Índice Nacional de Preços ao Consumidor Amplo (IPCA: 1980-2013). [S.1.], 2016. [Online; accesso 20-Março-2016]. Disponível em: $<$ http://www.ibge.gov.br>.

ILO. Non-standard employment around the World: Understanding challenges, shaping prospects. [S.1.]: Geneva: International Labour Office ILO, 2016.

IPEA. Bolsa família: uma década de inclusão e cidadania. Brasília: IPEA, 2013.

IPEA. Salário mínimo real - brasil (2000-2014). Brasília: IPEA, 2016, 2016. [Online; accesso 23-Março-2016]. Disponível em: <http://www.ipeadata.gov.br/>.

KREIN, J. D.; SANTOS, A. L. dos; NUNES, B. T. Trabalho no Governo Lula: avanços e contradições. Revista da ABET, v. 10, n. 2, jul/dez 2011.

LACERDA A. C.; REGO, M. M. R. M. S. R. A. M. Economia Brasileira. [S.1.]: São Paulo: Saraiva, 4a. ed, 2010. 
MAGNI, A. C.; CALVETE, C. S. Estudo comparado dos Sistemas de Proteção Social: Alemanha e França. Leituras de Economia Política, Campinas, n. 11, p. 1-26, dez, 2005.

NERI, M. C. De volta ao país do futuro: crise europeia, projeções e a nova classe média. Rio de Janeiro: FGV/CPS, 2012.

PIERRE, L. Les technologies de l'intelligence. Paris, La Découverte, 1990.

POLANYI, K. The place of economics in societies. In: POLANYI K; ARENSBERG, C. P. H. W. (Ed.). Trade and market in the early empires: economies in history and theory. [S.1.]: Nova York/Londres, The Free Press/Collier-Macmillan, 1957.

POLANYI, K. The economistic fallacy. Summer, v. 1, p. 9-18, 1977a.

POLANYI, K. The two meanings of economics. In: PEARSON, H. W. (Ed.). Livelihood of man. [S.1.]: Nova York: Academic Press, 1977b.

POLANYI, K. A grande transformação: as origens políticas e económicas do nosso tempo. [S.1.]: Rio de Janeiro: Campus, 2a. ed., 2012a.

POLANYI, K. A subsistência do homem e ensaios correlatos. [S.1.]: Rio de Janeiro: Contraponto, 2012b.

RAJAGOPAL, B. International law from below: Development, social movements and third world resistance. [S.1.]: Cambridge University Press, 2003.

RAMOS, L. A evolução da informalidade no Brasil metropolitano: 1991-2001. Texto para Discussao n.914, Instituto de Pesquisa Econômica Aplicada (Ipea), 2002.

RODRIK, D. Has globalization gone too far? Cambridge: Mass. Inst. Intern. Econ., 1997.

VARGAS, J. O mundo, o Brasil e a informalidade do trabalho: uma abordagem conceitual. Capital Científico, v. 14, n. 3, p. 144-156, 2016.

VARGAS, J. A gênese do mercado de trabalho e do fenômeno da informalidade no Brasil: Uma breve interpretação. Revista Eletrônica Documento Monumento, v. 22, p. 201-219, 2017.

VARGAS, J. A informalidade do mercado de trabalho: um desafio institucional permanente para a economia brasileira. [S.1.]: 1. ed. Saarbruken: Novas Edições Acadêmicas, 2017.

WILLIAMSON, J. What Washington means by Policy Reform. In: WILLIAMSON, J. (Ed.). Latin American Readjustment: How Much has Happened. [S.1.]: Washington: Institute for International Economics, 1989. 
180 Desenvolvimento socioeconômico brasileiro entre 1990 e 2012: considerações sobre a informalidade do trabalho à luz da teoria do duplo movimento de Polanyi

YANO, N. M.; MONTEIRO, S. M. M. Mudanças institucionais na década de 1990 e seus efeitos sobre a produtividade total dos fatores. Encontro Nacional de Economia (36.: 2008 dez.: Salvador, BA). Anais.. Salvador: ANPEC, 2008. 1 CD-ROM., 2008.

Recebido em maio de 2016 Aprovado em junho de 2018 